Bangladesh J. Bot. 38(1): 47-53, 2009 (June)

\title{
NUMERICAL ANALYSES OF WILD JURINEA SPP. (ASTERACEAE) IN TURKEY
}

\author{
Bekir Dogan*, Ahmet Duran ${ }^{1}$ and Erdogan Hakki ${ }^{2}$ \\ Department of Science Education, Faculty of Education, Selcuk University, Konya, Turkey \\ Key words: Numerical analyses, Jurinea, Asteraceae, Turkey
}

\begin{abstract}
Eighteen taxa of the genus Jurinea Cass. growing naturally in Turkey were classified by numerical taxonomic analysis. Morphological and palynological characters of each individual were measured and quantified on the basis of 51 traits. Ten plants were chosen randomly for the measurements of metric characters related to the external morphology of the taxa and the average values used for statistical analysis via NTSYS-pc package. Standardized data were used to generate the dendrogram that revealed the phenetic relationships of the taxa. Geographic distribution pattern of the Jurinea species appear to be closely related to the Anatolian Diagonal.
\end{abstract}

\section{Introduction}

Asteraceae is one of the largest Angiosperm families and according to recent classification it is divided into four subfamilies and 17 tribes (Hind and Beentje 1994). Within the family, a total of 1535 genera with 26,000 species have been recorded. Asteraceae is widely distributed within diverse regions ranging from Southwest of US, Mexico, Southern Brazil, South Africa, Middle and Southwest Asia as well as Australia. South America is accepted to be phylogenetically the geographic origin of the family (Bremer 1994).

Asteraceae is represented by 1209 species in the Flora of Turkey, out of which 447 are endemic, with an endemism of $37 \%$. With a total number of 134 genera, this family constitutes the second largest family of Turkish Flora (Davis et al. 1988, Özhatay and Kültür 2006). The genus Jurinea is represented with 18 species within Mediterranean and Irano-Turanian phytogeographic regions of Anatolia. Five of these species are endemic to Turkey resulting in an endemism of 27.8\% (Danin and Davis 1975, Dogan 2007, Dogan et al. 2007).

Jurinea Cass. is one of the most important genera within Asteraceae and it comprises about 200 species (Susanna et al. 2006). Native distribution of Jurinea specifically involves Central Asia, Iran, Turkey and the Mediterranean basin. It is located within the monophyletic tribe Cardueae which is constituted of five subtribes, namely, Carduinae, Centaureinae, Carlininae, Cardopatiinae and Echinopinae. Jurinea is a genus located within the subtribe Carduinae (Susanna et al. 2006).

Actual numerical-taxonomic studies of plant data were very scarce before the 1960s (Sokal and Sneath 1963). Numerical taxonomy has previously been applied in the classification of a number of plant taxa in Turkey (Togan et al. 1983, Kence et al. 1988, Dogan et al. 1992, Dogan 1997, Tutel et al. 2005). In this study, numeric taxonomic methods have been applied to classify 18 Jurinea taxa, on the basis of morphological and palynological characters.

\section{Materials and Methods}

Fifty one morphological and palynological characters were determined from the taxa of the genus Jurinea that are natural inhabitants of Turkey. List of species is given in Table 1. These characters were placed under eight headings and were included in the life form, shoot and leaf

*Corresponding author: <bdogan@selcuk.edu.tr $>{ }^{1}$ Department of Biology Education, Faculty of Education, Selcuk University, Konya, Turkey. ${ }^{2}$ Department of Field Crops, Faculty of Agriculture, Selcuk University, Konya, Turkey. 
characteristics, flower structure, capitulum, involucrum, fillaries and achen characteristics (Table 2). Data obtained from 18 taxa and a total of 51 traits were organized into a matrix of $51 \times 18$ dimensions. The mean of ten individual sample measurements related to the external morphologies were considered for every metric character of the taxa. Analyses of standardized data were conducted using the NTSYS-pc package programme (Applied Biostatistic, Exeter Software, Setauket, New York, USA). Similarity coefficients were calculated and phenograms were constructed using the unweighted pair-group method with the arithmetic mean (UPGMA) method (Rohlf 1992). In order to determine the ability of numerical data to display the interrelationships among the samples, principle co-ordinate analysis (PCoA) of pairwise genetic distances (Nei 1972) was also conducted using NTSYS-pc package.

Table 1. Origin of the materials and herbaria where the vouchers of Jurinea spp. are deposited.

\begin{tabular}{|c|c|}
\hline Species & Origin, voucher \\
\hline J. consanguinea & $\begin{array}{l}\text { Turkey, Konya: Sultan Mountains, } 1130 \text { m, } 37^{0} 14.913 \text { N, } 038^{0} 49.427^{\prime} \mathrm{E}, 18.07 .2006 \text {, } \\
\text { B.Doğan } 1501 \text { (KNYA) }\end{array}$ \\
\hline J. tortumensis & $\begin{array}{l}\text { Turkey, Erzurum: From Erzurum to Tortum, } 1880 \mathrm{~m}, 40^{\circ} .15 .08^{\circ} \mathrm{N}, 041^{\circ} .31 .59^{\prime} \mathrm{E} \text {, } \\
\text { 31.05.2003, A.Duran } 6170 \text { (KNYA), Endemic. }\end{array}$ \\
\hline J. alpigena & $\begin{array}{l}\text { Turkey, Karabük, Keltepe, } 1630-1680 \mathrm{~m}, 41^{\circ} 03.796^{\prime} \mathrm{N}, 032^{\circ} 27.781^{\prime} \mathrm{E}, 21.07 .2006 \text {, } \\
\text { B.Doğan } 1510 \text { (KNYA), Endemic. }\end{array}$ \\
\hline J. cadmea & $\begin{array}{l}\text { Turkey, İzmir, Ödemiş, Bozdağ, 1650-1750 m, 38⒛671' N, 02806.403' E, } \\
\text { 19.07.2006, B.Doğan } 1503 \text { (KNYA), Endemic. }\end{array}$ \\
\hline J. mollis & $\begin{array}{l}\text { Turkey, Kirklareli, from Vize to Sergen, Quercus sp. forest, } 310-320 \mathrm{~m}, 41^{\circ} 37.312^{\prime} \\
\mathrm{N}, 027^{\circ} 40.950^{\prime} \text { E, 07.07.2005, B.Doğan } 1504 \text { (KNYA) }\end{array}$ \\
\hline J. macrocalathia & $\begin{array}{l}\text { Turkey, Tekirdağ, Malkara, Kumbağ, } 5-25 \mathrm{~m}, 40^{\circ} 51.852^{\prime} \mathrm{N}, 027^{\circ} 27.604^{\prime} \mathrm{E} \text {, } \\
\text { B.Doğan } 1507 \text { (KNYA) }\end{array}$ \\
\hline J. turcica & 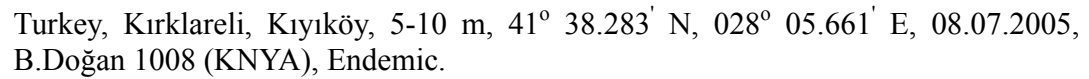 \\
\hline J. pontica & $\begin{array}{l}\text { Turkey, Kocaeli, Sapanca lake slopes, } 40-50 \mathrm{~m}, 40^{\circ} 44.118^{\prime} \mathrm{N}, 033^{\circ} 36.871^{\prime} \mathrm{N} \text {, } \\
\text { 09.07.2005, B.Doğan } 1011 \text { (KNYA), Endemic. }\end{array}$ \\
\hline J. pulchella & $\begin{array}{l}\text { Turkey, Van, Campus of Yüzüncü Y1l University, } 1650 \text { m, 05.08.2005, B.Doğan } \\
1025 \text { (KNYA) }\end{array}$ \\
\hline J. kilaea & $\begin{array}{l}\text { Turkey, Kırklareli, Kasatura (Kastros), beach dunes, } 1-5 \text { m, } 41^{\circ} 35.273^{\prime} \text { N, } 028^{\circ} 08.566^{\prime} \\
\text { E, 08.07.2005, B.Doğan } 1010 \text { (KNYA) }\end{array}$ \\
\hline J. stoechadifolia & $\begin{array}{l}\text { Turkey, Çankırı, from Çankırı to Ilgaz, } 830 \mathrm{~m}, 39^{\circ} 54.362^{\prime} \mathrm{N}, 040^{\circ} 41.903^{\prime} \mathrm{E} \text {, } \\
\text { 23.09.2006, B.Doğan 1522, A.Duran \& H.Duman (KNYA) }\end{array}$ \\
\hline J. cypria & $\begin{array}{l}\text { Turkey, Mersin, Mut, Mountain pasture of Kozlar, } 1320 \text { m, 37 } 14.913^{\prime} \text { N, } 038^{\circ} 49.427^{\prime} \\
\text { E, 28.07.2006, B.Doğan } 1500 \text { (KNYA) }\end{array}$ \\
\hline J. macrocephala & $\begin{array}{l}\text { Turkey, Konya, Aydos Mountain, Kayasaray village, } 1700 \mathrm{~m}, 37^{\circ} 22.249^{\prime} \mathrm{N} \text {, } \\
034^{\circ} 17.308^{\prime} \mathrm{E}, 31.07 .2005 \text {, B.Doğan } 1017 \text { (KNYA) }\end{array}$ \\
\hline J. aucherana & $\begin{array}{l}\text { Turkey, Erzincan, Spikor mountain, } 760-2095 \mathrm{~m}, 39^{\circ} 53.429^{\prime} \mathrm{N}, 039^{\circ} 45.778^{\prime} \mathrm{E} \text {, } \\
\text { 22.08.2006, B.Doğan } 1519 \text { (KNYA) }\end{array}$ \\
\hline J. ramulosa & $\begin{array}{l}\text { Turkey, Kahramanmaraş, Ahir Mountain, } 1390 \mathrm{~m}, 37^{\circ} 37.057^{\prime} \mathrm{N}, 036^{\circ} 52.074^{\prime} \mathrm{E} \text {, } \\
\text { B.Doğan } 1513 \text { (KNYA) }\end{array}$ \\
\hline J. brevicaulis & $\begin{array}{l}\text { Turkey, Erzincan, Spikor Mountain, } 1420 \mathrm{~m}, 39^{\circ} 47.363^{\prime} \mathrm{N}, \quad 039^{\circ} 29.940^{\prime} \text { E, } \\
\text { 07.08.2005, B.Doğan } 1028 \text { (KNYA), Endemic. }\end{array}$ \\
\hline J. cataonica & $\begin{array}{l}\text { Turkey, Erzincan, Spikor Mountain, } 10 \mathrm{~km}, 1750 \mathrm{~m}, 39^{0} 47.954^{\prime} \mathrm{N}, 039^{0} 30.343^{\prime} \mathrm{E} \text {, } \\
\text { 07.08.2005, B.Doğan } 1029 \text { (KNYA), Endemic. }\end{array}$ \\
\hline J. ancyrensis & $\begin{array}{l}\text { Turkey, Elazı̆̆, from Keban to A } \breve{g l} 1,800-850 \mathrm{~m}, 38^{\circ} 48.692^{\prime} \mathrm{N}, 038^{\circ} 43.929^{\prime} \mathrm{E} \text {, } \\
\text { 21.08.2006, B.Doğan } 1516 \text { (KNYA) }\end{array}$ \\
\hline
\end{tabular}


Table 2. List of characters used in numerical taxonomic analysis.

\begin{tabular}{|c|c|}
\hline A-Life forms & F-Involucrate \\
\hline 1-Hemicryptophyte (0), Chamaephyte (1) & 27- Hemispherical (0), globose (1) obconical (2), ovate- \\
\hline B-Stems & oblong (3) \\
\hline 2-Stem length $(\mathrm{cm})$ & 28-Involucrum length ( $\mathrm{mm})$ \\
\hline 3-Stem thickness (mm) & 29-Involucrum width (mm) \\
\hline 4-Stem hairiness; sparsely (0), densely (1) & G-Phyllaries \\
\hline 5-Stem base hairiness; not woolly (0), woolly (1) & $30-5$ seriate $(0), 5-6$ seriate $(1), 6-7$ seriate $(2), 7-8$ \\
\hline 6-Stem branched; absent (0), present (1) & seriate $(3)$ \\
\hline 7-Stem present; absent (0), present (1) & 31-Phyllaries adpressed (0), adpressed to lax (1), lax (2) \\
\hline 8 -Stem decumbent (0), erect (1) & 32-Outer phyllaries length (mm) \\
\hline C-Leaves & 33-Outer phyllaries width (mm) \\
\hline 9-Stem leaves; absent ( 0 ), decreasing in size & 34-Inner phyllaries length ( $\mathrm{mm})$ \\
\hline upwards (1), present (2), & 35-Inner phyllaries width (mm) \\
\hline 10 -Stem leaf length $(\mathrm{cm})$ & 36-Phyllaries reflexed (0), not reflexed (1) \\
\hline 11-Stem leaf width $(\mathrm{cm})$ & 37-Phyllaries not keel (0), keel (1) \\
\hline 12-Stem leaf shape; entire (0), pinnatisect (1) & H-Achenes \\
\hline 13-Basal leaf length $(\mathrm{cm})$ & 38-Achene smooth (0), tetragonal (1) \\
\hline 14-Basal leaf width $(\mathrm{cm})$ & 39-Achene length $(\mathrm{mm})$ \\
\hline & 40-Pappus scabrous (0), barbellate (1), plumose (2) \\
\hline 17-Basal leaf narrow; absent (0), present (1) & 41-Pappus length (mm) \\
\hline 18-Basal leaf rosulate $(0)$, not rosulate $(1)$ & I-Pollens \\
\hline D-Flowers & 42-Polar axis length $(\mu \mathrm{m})$ \\
\hline 19-Corolla lobe length $(\mathrm{mm})$ & 43-Equatorial axis length $(\mu \mathrm{m})$ \\
\hline 20-Corolla tube length (mm) & 44-Exine thickness $(\mu \mathrm{m})$ \\
\hline 21-Anther length $(\mathrm{mm})$ & 45-Intine thickness $(\mu \mathrm{m})$ \\
\hline 22-Style length (mm) & 46-Colpus length $(\mu \mathrm{m})$ \\
\hline 2L-style length (mm) & 47-Colpus width $(\mu \mathrm{m})$ \\
\hline E-Capitula & 48-Pore length $(\mu \mathrm{m})$ \\
\hline 23-Capitula length $(\mathrm{cm})$ & 49-Pore width $(\mu \mathrm{m})$ \\
\hline 24-Capitula width $(\mathrm{cm})$ & $50-\mathrm{Clg} / \mathrm{Clt}$ ratio \\
\hline 25-Capitula solitary (0), two or more than (1) & 51- Polar axis / Equatorial axis ratio \\
\hline 26-Capitula corymbose $(0)$, not corymbose $(1)$ & \\
\hline
\end{tabular}

\section{Results and Discussion}

In the present study, 18 taxa were evaluated on the basis of data matrix generated from 51 characters $(18 \times 51)$. Within the data set, 41 characters were related to the external morphology and the remaining ten characters were determined from palynologic data. Cluster analysis was conducted based on both discrete and continuous data that were first standardized. Numerical classification results on phylogenetic relationships of Jurinea taxa were determined according to the phenogram resulting from the UPGMA clustering (Fig. 1).

When the phenogram was studied, it was observed that all the Jurinea species were composed of two major groups. The species of the first group, namely J. consanguinea, J. pontica, J. pulchella, J. kilaea, J. mollis, J. macrocalathia, J. turcica, J. alpigena constituted the taxa with pinnatilobed to pinnatisect leaves. These taxa, with the exception of $J$. consanguinea, are distributed at the Western part of the Anatolian Diagonal. While J. consanguinea is widely grown at the West of the Diagonal, it is also present on the Diagonal as well as at the Eastern parts of it and appear to be very restricted. It is worth noting that this species is a transition taxon with mostly pinnatisect leaves but some of the samples were also observed with entire leaves. This species with various growing habitats, was observed not to be influenced by the geographical, 
topographical and climatological factors determined by the Anatolian Diagonal. Another species, $J$. pulchella that is distributed at the Eastern parts of the Diagonal and possesses both pinnatisect and entire leaves, that is also expected to be present within both groups was observed within the Western group with pinnatisect leaves.

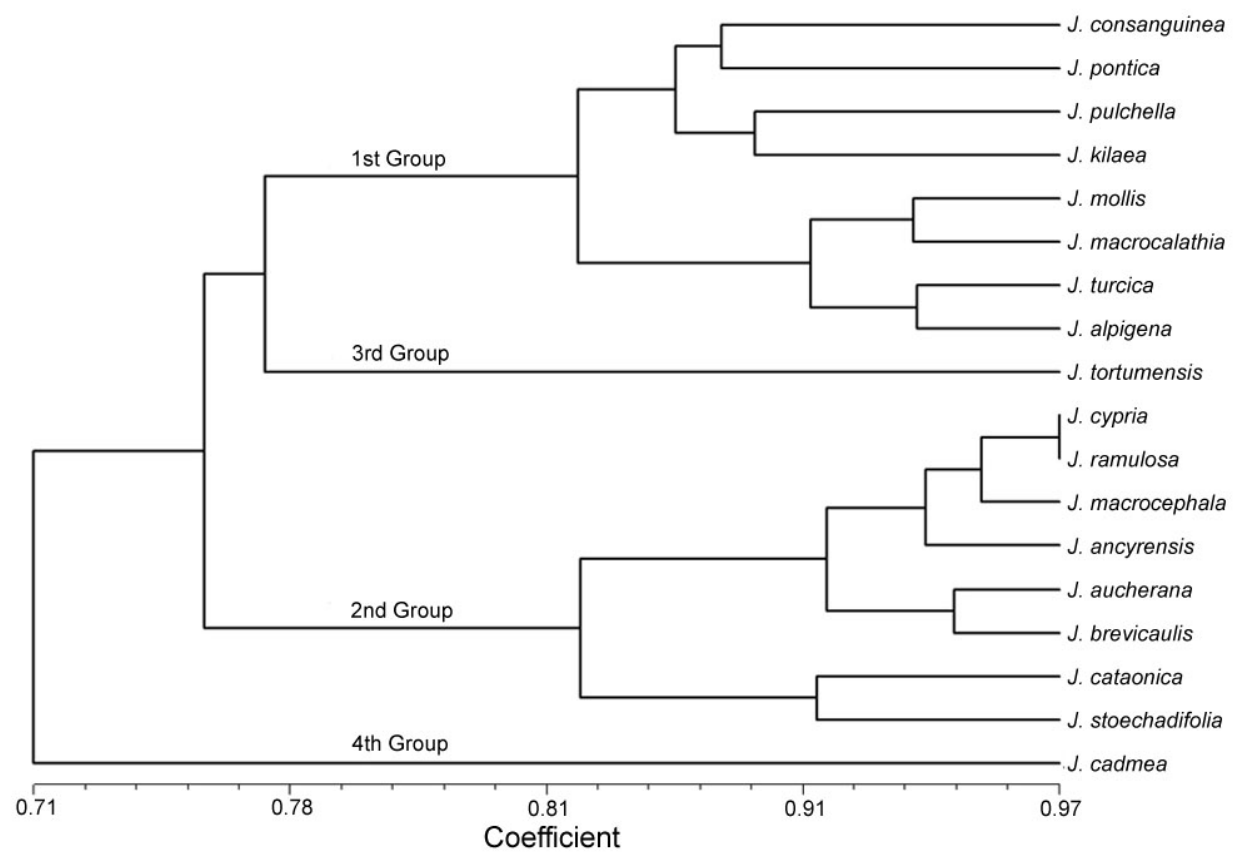

Fig. 1. Phenogram showing the relationships within the genus Jurinea.

When the Jurinea taxa naturally grown in Turkey were examined, the ones with entire leaves that inhabit the Eastern parts of the Anatolian Diagonal were seen to be the taxa that are evolutionary more advanced. That is because entirety of the leaves is an advanced character (Stace 1992). J. pulchella is a species localized to Irano-Turanian phytogeographic region, but in previous geological times, due to different climatic conditions it was probably distributed in a more extensive region. Considering the remaining Western taxa, the second branch that was constituted of the species J. mollis, J. macrocalathia, J. turcica and J. alpigena, they varied from the first branch at a level of $85 \%$. J. kilea is the only species collected from a coastal region of Black Sea, namely Kirklareli-Kiyikoy, and within the limits of the present study it was grouped with J. pulchella. This is in accordance with our previous work where the genetic relationships of 14 Jurinea species were determined via Inter Simple Sequence Repeats or simply ISSR (Dogan et al. 2007). Interestingly, in that study, J. pulchella appeared as a species loosely attached to the taxa that constituted the second major group with samples mainly collected from the Eastern parts of the Anatolian Diagonal.

The taxa that constituted the second group include J. cypria, J. ramulosa, J. macro-cephala, J. ancyrensis, J. aucherana, J. brevicaulis, J. cataonica and J. stoechadifolia. Within this group, high level of morphological similarity was observed. Leaves of all taxa were entire, their stems were branched and the number of capitula per plant was more than one. With the exception of $J$. stoechadifolia, the taxa constituting this group are grown either on or at the East of Anatolian Diagonal, their distribution is closely related to the Diagonal. 
Overall, the samples of the Western Anatolian Diagonal were equally distinct from $J$. tortumensis which appeared as the third discrete branch on the numerical dendogram. Its leaves are entire, undulate or lobed to a certain degree. With leaves from slightly pinnatilobed to lobular it presents an intermediate species. Additionally, with its hairless leaves and old-leaf remains abundant at the plant base it is very distinct from the other taxa.

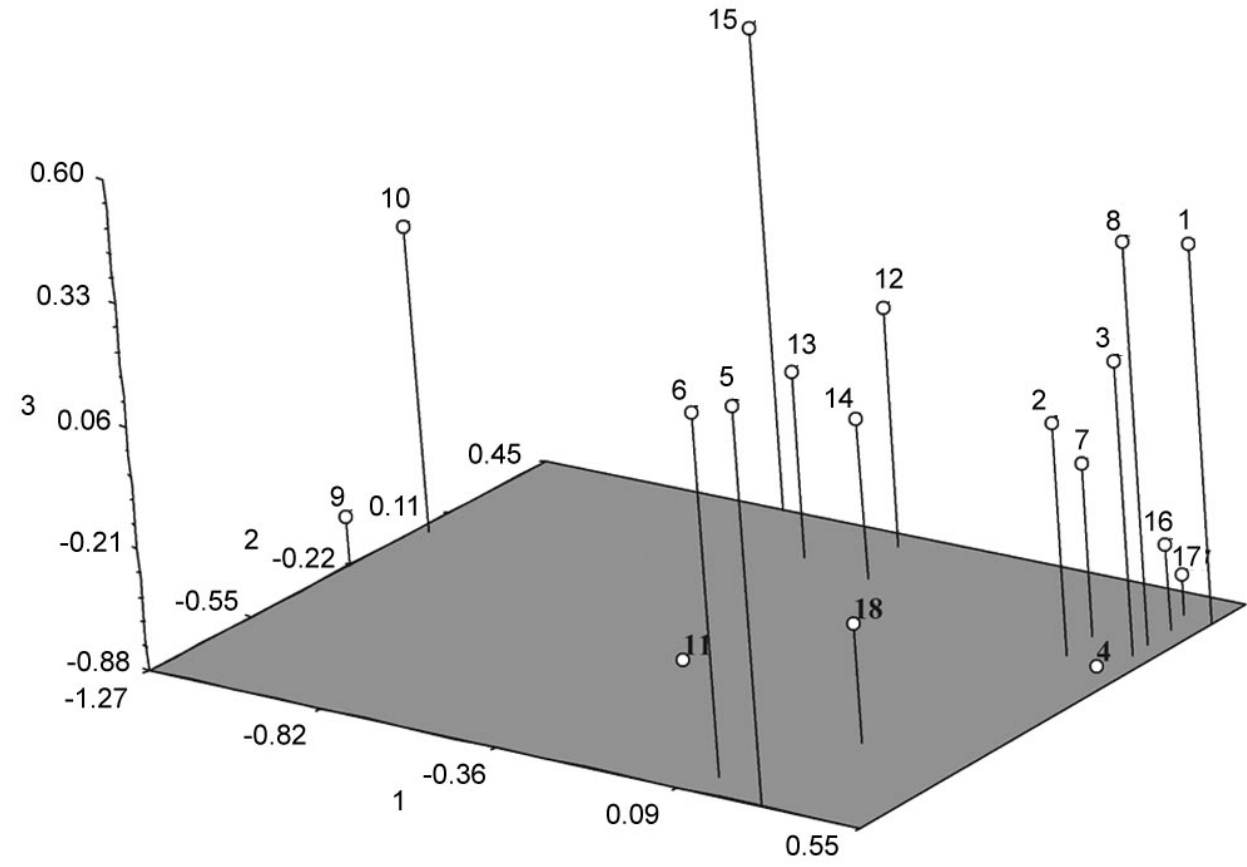

Fig. 2. Principal coordinate analysis of Jurinea species. 1. Jurinea consanguinea, 2. J. tortumensis, 3. J. mollis, 4. J. cadmea, 5. J. macrocalathia, 6. J. turcica, 7. J. alpigena, 8. J. pontica, 9. J. cypria, 10. J. macrocephala, 11. J. aucherana, 12. J. ramulosa, 13. J. brevicaulis, 14. J. cataonica. 15. J. ancyrensis, 16. J. pulchella, 17. J. stoechadifolia, 18. J. kilaea.

Although $J$. stoechadifolia is distributed in the West of the Diagonal and since its leaves are entire, it has a branched stem and the number of its capitula is more than one, this taxon was placed in the second group. This species is also distributed in Bulgaria and the former Soviet Union (Kozuharov 1964, Iljin 1962). Among the Jurinea species of Turkey J. stoechadifolia is the only taxon that is localized to gypsy soils. When the global distribution of this species is considered, it can be seen that its distribution in Turkey is not related to the Anatolian Diagonal.

In the study of Dogan et al. (2007), cluster analysis via molecular data was insufficient in clearly discriminating the species of the sub-branch of Western Diagonal group that was constituted of J. brevicaulis, J. cataonica and J. ancyrensis. In contrary, in the present study, it was impossible to distinguish the species $J$. cypria (a species not used in our previous work) from $J$. ramulosa. However, this distinction was possible with the use of Principle Coordinate Analysis $(\mathrm{PCoA})$. The related species were clearly separated by the first and the second principle coordinates ( $\mathrm{PCo} 1 \& \mathrm{PCo} 2)$. Both our previous molecular study and the current phenotypical analysis determined a close relationship between J. ramulosa and J. macrocephala. When the first two coordinates are considered, the last branch represented by J. cadmea in cluster analysis, was found to be grouped with the taxa of the first group of the dendogram. A comprehensive discrimination of the remaining taxa was also possible with the use of the first three coordinates 
(Fig. 2). Not to mention, effective discrimination power of PCoA was also proven elsewhere (Dogan et al. 2007).

As of the stem character, of all the Jurinea taxa of Turkey, J. cadmea, has stems. The stemless species J. cadmea that is grown at the rocky places of Bozdag region at Western Anatolia is a local endemic species. By itself, this taxon was constituted of fourth separate branch on the numerical dendrogram. In other words, it served as an outlier sample.

Overall, the phenogram generated with the use of the morphological and the palynological data determined that the morphologically similar taxa gathered under the same branch. Similarly, numerical data presented highly similar clustering profile with that of the molecular data (Dogan et al. 2007). Additionally, the discrimination of the taxa with the use of both the numerical and the molecular phylogeny was also found to be closely related to the Anatolian Diagonal (Fig. 3). The existence of the Jurinea species is given in Fig. 3. Some taxa are rarely distributed outside the given areas.

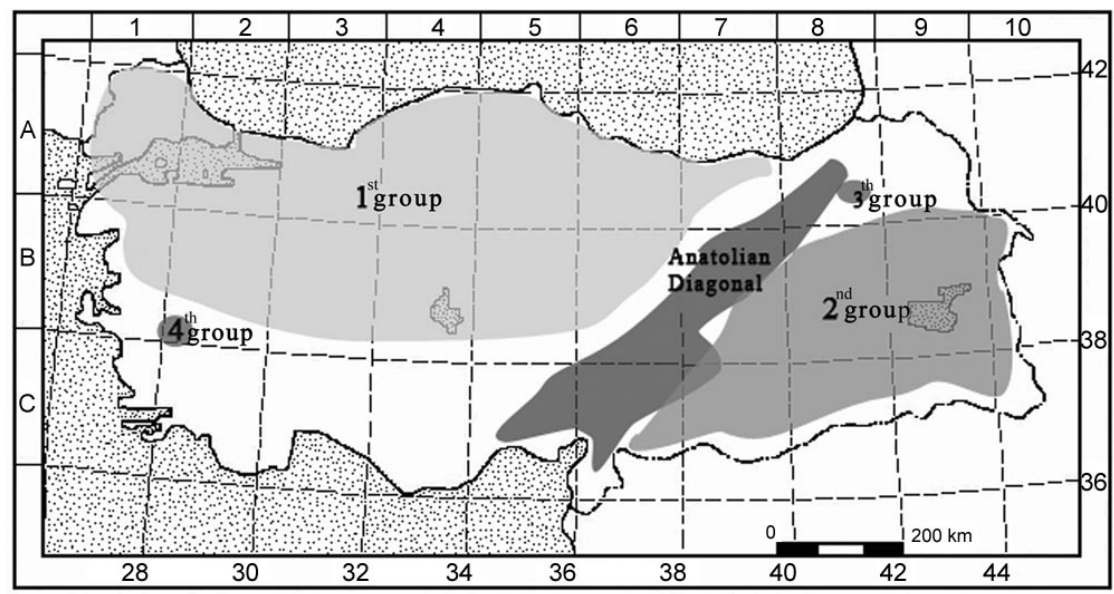

Fig. 3. Distribution of four Jurinea groups in Anatolia. The groups were obtained by the use of phenetic analysis of the Turkish taxa.

It appeared that, the phytogeographical distribution of the genus Jurinea was found to be closely related to the Anatolian Diagonal. The Diagonal is an interesting biodiversity area and it is rich in local endemic plants, than in any Mediterranean region (Duran et al. 2005). The concept of the Diagonal was first proposed by Davis who defined it as an oblique belt running from the northeast towards south-west to the Anti-Taurus: it was then divided into two, with one branch to the Amanus (Amanos Dağları), the other to the Cilician Taurus (Davis 1971). Thirty three per cent of the total species growing in Turkey are found along the Diagonal, while 5 per cent are more or less restricted to it. One explanation for the present richness of the species is neo-endemism and distribution patterns of the plants related to the Diagonal (Ekim and Güner 1986). Based on the physiographic disturbances that isolated the Jurinea species grown on the Anatolian Diagonal and its eastern parts from the species grown along the western regions of the Diagonal, two major taxonomical groups were constituted. Numerical data of this study provided strong and reliable support to clearly reveal biogeographic distribution of this genus and the taxonomic relationships.

\section{Acknowledgements}

The authors express their thanks to TUBITAK (Project No. TBAG-105-T-355) and The Scientific Investigation Projects Coordinate Office of The Selcuk University (Project No: 05401046) for financial support. 


\section{References}

Bremer, K. 1994. Compositae. Cladistics and classification, Portland, Oregon. Timber Press. U.S.A.

Danin, A. and P.H. Davis. 1975. Jurinea Cass. In: Flora of Turkey and the East Aegean Islands. Davis, P. H. (ed.) Vol. 5. Edinburgh Univ. Pres, Edinburgh.

Davis, P.H. 1971. Distribution patterns in Anatolia with particular reference to endemism. In: Plant Life of South-West Asia. Davis, P. H., Harper, P.C. \& Hedge, I.C. (Eds.), pp. 15-28. Bot.l Soc., Edinburgh, Edinburgh.

Davis, P.H. Tan, K. and Mill R. R. 1988. Flora of Turkey and the East Aegean Islands, Vol. 10. Edinburgh Univ. Press, Edinburgh.

Dogan, B. 2007. Türkiye Jurinea Cass. (Asteraceae) Cinsinin Revizyonu. Doktora Tezi, Selçuk Üniversitesi, Fen Bilimleri Enstitüsü, Konya.

Dogan, B., A. Duran and E.E. Hakki. 2007. Phylogenetic relationship analysis of Jurinea Cass. (Asteraceae) species from Turkey as revealed by Inter-Simple Sequence Repeat Amplification. Ann. Bot. Fennici 44(5): 353-358.

Dogan, M. 1997. Numerical taxonomic study on the genus Alopecurus L. (Gramineae). Ot Sistematik Botanik Dergisi 4: 71-76.

Dogan, M., A. Kence and Ç. Tigın. 1992. Numerical taxonomic study on Turkish Lathyrus (Leguminosae). Edinb. J. Bot. 49: 333-341.

Duran, A., M. Sağıroğlu. and H. Duman. 2005. Prangos turcica (Apiaceae), a new species from South Anatolia, Turkey. Ann. Bot. Fennici 42: 67-72.

Ekim, T. and A. Güner. 1986. The Anatolian Diagonal: fact or fiction. Proc. Soc. Edinburgh. 89B: 69-77.

Hakki, E.E., S.A. Kayis, E. Pinarkara and A. Sag. 2007. Inter Simple Sequence Repeats separate efficiently Hemp from Marijuana (Cannabis sativa L.). Electronic J. Biotechnol. [online]. 15 October 2007, Vol. 10, No. 4. Available from Internet: http://www.ejbiotechnology.info/content/vol10/ issue4/full/4/index. html. ISSN 0717-3458.

Hind, D.J.N. and H.J. Beentje. 1994. Compositae: Systematics. Proc. Intl. Compositae Conf., Kew 1: 1-7.

Iljin, M.M. 1962. Jurinea Cass. In: Flora of the USSR Shiskin, B.K., Bobrov, E.G. (Eds.), 27: 661-884.

Kence, A, M. Dogan and Ç. Tıgın. 1988. Türkiye'deki Lathyrus L. (Leguminosae) türlerinin nümerik taksonomi metodu ile sinıflandırılması. IX. Ulusal Biyoloji Kongresi, Sivas, cilt I, pp. 417-423.

Kozuharov, S., 1964. Jurinea Cass. In: Flora Europaea, Tutin, T.G., Heywood, V.H., Burges, N.A., Valentine, D.H., Walters, S.M., Webb, D.A. (Eds.). 4: 218-220, Cambridge Univ. Press, Cambridge.

Nei, M. 1972. Genetic distance between populations. Am. Nat. 106: 283-292.

Özhatay, N. and Ş. Kültür. 2006. Check-list of additional taxa to the Supplement Flora of Turkey III. -Tr. J. Bot. 30: 281-316.

Rohlf, F.J. 1992. NTSYS-pc: Numerical taxonomy and multivariate analysis system, version 2.0. State Univ. N.Y., Stony Brook, NY.

Sokal, R.R. and P.H.A. Sneath. 1963. Principles of numerical taxonomy. Freeman, San Francisco.

Stace, C.A. 1992. Plant Taxonomy and Biosystematics. Cambridge Univ. Press, Cambridge.

Susanna, A., N. Garcia-Jacas, O. Hidalgo, R. Vilatersana and T. Garnatje. 2006. The Cardueae (Compositae) revisited: Insights from its, trnL-trnF, and matK nuclear and chloroplast DNA analysis. Ann. Missouri Botanical Garden 93(1): 150-171.

Togan, I., N. Aydem and A. Kence. 1983. A numerical taxonomic study of Carthamus taxa in Turkey. In: Numerical Taxonomy. Felsenstein, J. (Ed.). NATO ASI Series. Berlin: Springer-Verlag.

Tutel, B., İ. Kandemir, S. Kuş and A. Kence. 2005. Classification of Turkish Plantago L. Using Numerical Taxonomy. Turk. J. Bot. 29: 51-61.

(Manuscript received on 27 July, 2008; revised on 31 December, 2008) 